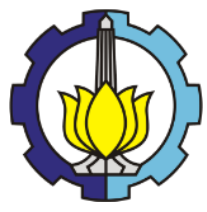

$8^{\text {th }}$ International Conference on

Architecture Research and Design (AR+DC)

November 1-2, 2016

\title{
Survey on household energy consumption of public apartments in Bandung City, Indonesia
}

\author{
Usep Surahman ${ }^{a^{*}}$, Johar Maknuna ${ }^{\mathrm{a}}$, Erna Krisnanto ${ }^{\mathrm{a}}$ \\ ${ }^{a}$ Universitas Pendidikan Indonesia, Jl. Dr. Setiabudhi No. 227, Bandung 40154, Indonesia \\ *Corresponding author. Tel.: +62-89634730153; fax: +62 -22- 2011576 \\ E-mail address: usep@upi.edu
}

\begin{abstract}
Indonesia has been experiencing population and high economic growth in line with rapid urbanization. As a consequence, the needs for living areas increased faster and enormous number of residential buildings, especially apartments, have been developed in major cities, such as Bandung, resulting in further growth of energy consumption. Thus, it is necessary to develop energysaving sustainable apartments in Indonesia in order to cope with escalating energy issues. This paper reveals the detailed profiles of household energy consumption of apartments in Bandung City, Indonesia. A survey within the city was conducted ( $\mathrm{n}=100)$ in 2016 to obtain household energy consumption data of public apartments. The detailed information about household appliances and domestic energy consumption profile among households were investigated through the face-to-face interviews and the measurement of appliances' capacities by using the watt checker. The annual average energy consumption including electricity and gas was calculated. The results show that the annual average operational energy for public apartments are $9.8 \mathrm{GJ} / \mathrm{year}$. The annual average energy for cooking accounts for the largest percentage (48\%) of operational energy followed by refrigerator $(27 \%)$, lighting (10\%), entertainment (9\%), cooling (3\%), etc. The profiles of $\mathrm{CO}_{2}$ emissions are similar with those of energy and the potential energy-saving strategies for apartments in Indonesia were proposed.
\end{abstract}

Keywords: household energy consumption; operational energy; energy saving; apartment; Indonesia

\section{Introduction}

The ultimate purpose of this study is to propose low energy and low carbon apartment buildings in major cities of Indonesia. Over the last few decades, Indonesia has been experiencing high economic growth in line with rapid urbanization and population growth. The percentage of people living in urban areas reached approximately 53\% in 2014 (United Nation, 2014). Consequently, the need for living spaces increased rapidly, and an enormous number of residential buildings including apartments have been developed, especially in major cities. This tremendous urbanization found in the major cities sees a large increase in urban energy consumption.

In Indonesia, the household sector contributed $33.2 \%$ of the nationwide final energy consumption during the period of 2000-2013 (PUSDATIN ESDM, 2014). The household energy consumption is expected to increase dramatically as the middle class in urban areas rises in the near future (JETRO, 2011). Percentage of middle classes in Indonesia increased from 38\% in 2003 to 57\% in 2010 (Asian Development Bank, 2010). Hence, the housing demand for this respective class is expected to largely increase in the near future. Since most of the major cities such as Jakarta and Bandung are already crowded with landed houses, these cities now are extending vertically. In fact, the governments of these cities intensively promote the development of vertical houses to cope with housing demand and limited land and green space. In the city of Bandung for instance, the number of apartments has doubled in the last five years only. Therefore, energy-saving strategies are essential to be introduced further to make the cities more sustainable. 
A few studies of household energy consumption were conducted in Indonesia. For instance, evaluated on the life cycle energy consumption of high-rise apartments in Jakarta (Utama \& Gheewala, 2009). Furthermore, Investigated the life cycle energy of single landed houses with different materials of walls in Semarang (Utama \& Gheewala, 2008). Life cycle energy and $\mathrm{CO}_{2}$ emissions of planned houses in seven large cities in Indonesia (Kurdi, 2005). The above studies provide rare and useful results of energy consumption in residential and apartment buildings of Indonesia. However, these studies only focused on mass/planned houses and private apartments. In Indonesia, public apartments will be typical of apartments in major cities rather than the said apartments in near future as discussed in Section 2.1.

This study, which focuses on public apartments in major cities of Indonesia, aims to assess the household energy consumption and $\mathrm{CO}_{2}$ emissions of urban (public) apartment buildings. The surveys were conducted in the citiy of Bandung ( $n=100$ apartment units) in March 2016 to obtain household energy consumption profiles of these buildings. The results of this analysis will provide useful insights for policy making in energy policy for achieving low-energy and low-carbon societies in Indonesia.

\section{Research theory and methods}

\subsection{Case study apartments}

Bandung was selected as the case study city, which represent rapidly developing city. The city was located in the region of Java in Indonesia. Bandung, the capital of West Java Province, had a population of 2.45 million in 2012 (BPS Kota Bandung, 2013) and it experiences hot and humid tropical climate. The monthly average temperature in Bandung was $22.9-23.9{ }^{\circ} \mathrm{C}$ because of the relatively high altitude. On average, Bandung is situated $700-800 \mathrm{~m}$ above the sea level.

The city of Bandung experiences rapid urbanization with high housing growth that can well-represent the housing stock in major cities of Indonesia. Built land in Bandung is predicted to be $85 \%$ as of 2013 with $54 \%$ is saturated by housing (BAPPEDA Kota Bandung, 2014). Therefore, the government stressed the importance of encouraging development of apartments in the city to avoid the decrease of green space. The number of apartments continues to grow.

According to Act No. 20/2011 regarding apartments, there are three categories of apartment in Indonesia today based on ownership and management. They are private, public and special apartments. Private apartments are constructed and owned by private companies, whereas the rest are owned and managed by government. The special apartments are constructed for special purpose and are limited construction. Recently, these two categories, i.e. private and especially for public apartments, are highly demanded by emerging low-to-middle class market due to population growth and land availability issues.

In most major cities in Indonesia, public apartments, called "Rumah Susun", would account for the largest proportion of the existing apartment stocks in the near future. Bandung Government will constructed 100 public apartment tower in next 3 years (PEMPROV JABAR, 2011) in order to provide housing demand within the City (see Fig.1.)

We assumed that subsets of the population for respective apartment units were homogenous in Indonesia. Therefore, the disproportional stratified sampling was applied, thus a large sample size was not necessary to represent the entire population (510 thousand units in Bandung). Statistically, in most cases, a sample size of less than about 30 respondents will provide too little certainty. Usually, experienced researchers regard a sample of about 100 respondents as a minimum sample size for large populations (Bryant \& Yarnold, 1995). Several typical apartments were selected from the cities of Bandung ( 2 areas), respectively. A total of 100 residential units were then chosen randomly in the selected neighborhoods by considering the distance from city center and their establishment years, respectively (see Table 1).

As shown in Table 1, the average household size was about 2-3 persons for apartments with a small variation between the two. The monthly average household income was also investigated by a multiple-choice question. As expected, the average income varies. As shown, the total gross floor area also varies. The largest percentage of gross floor area was less $18-24 \mathrm{~m}^{2}$ around $67 \%$ for apartment units. 


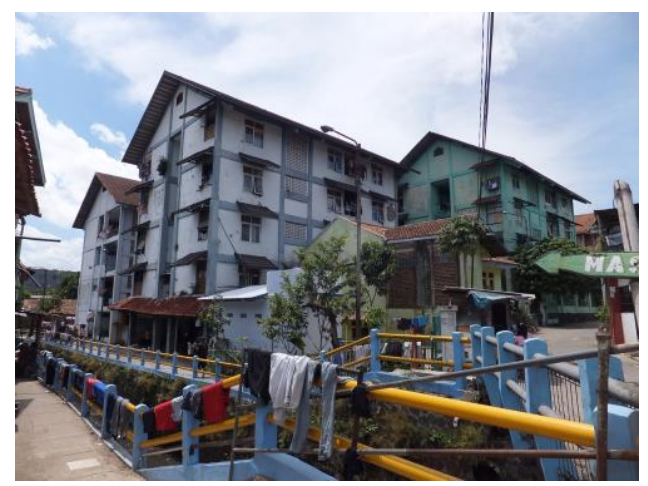

Table 1. Socio-economic profile of respondents.

\begin{tabular}{|c|c|}
\hline Profiles & Public apartments \\
\hline Sample size & 100 \\
\hline Male & 51.0 \\
\hline Female & 49.0 \\
\hline \multicolumn{2}{|l|}{ Age $(\%)$} \\
\hline$<40$ (years old) & 55.6 \\
\hline $40-49$ & 35.3 \\
\hline $50-59$ & 8.1 \\
\hline $60-64$ & 1.0 \\
\hline$>65$ & 0.00 \\
\hline Household size (persons) & 2.04 \\
\hline \multicolumn{2}{|c|}{ Monthly household income (\%) } \\
\hline$<153$ (US\$) & 10.5 \\
\hline $153-307$ & 64.0 \\
\hline $308-615$ & 25.5 \\
\hline$>615$ & 0.00 \\
\hline \multicolumn{2}{|l|}{ Total floor area (\%) } \\
\hline$<18\left(\mathrm{~m}^{2}\right)$ & 0.00 \\
\hline $18-24$ & 67.00 \\
\hline $25-36$ & 32.00 \\
\hline$>36$ & 1.00 \\
\hline
\end{tabular}

2.

Fig. 2. Household energy consumption survey.

The detailed household energy consumption data are necessary for the analysis of operational energy. Since the energy consumption data were not available in the City, the detailed interviews and measurement of appliance capacity by using watt checkers (MWC01, OSAKI) were conducted in order to obtain the data (see Fig. 2). Energy consumption for respective household appliances was estimated through multiplying the number of appliances by their usage time and electric capacity, which were acquired through the interviews and measurements. The annual average household energy consumption was then calculated by combining consumption for all the appliances. As described earlier, the seasonal variation in climatic conditions is not large in Bandung. Therefore, the usage time of appliances was assumed to be constant throughout the year. Nevertheless, the small seasonal changes of air temperature and humidity were considered in the estimation of energy consumption of air-conditioners and refrigerators, although the resultant changes were found to be negligible. 
Table 2. Emission factors of energy sources for Indonesia.

\begin{tabular}{lc}
\hline Energy sources & Emission factor $(\mathrm{kg} / \mathrm{GJ})$ \\
\hline Electricity & 196.9 (IEA, 2012) \\
Coal & 94.6 (IPCC, 2006) \\
Oil & 73.3 (IPCC, 2006) \\
Natural gas & 56.1 (IPCC, 2006) \\
Kerosene & 71.9 (IPCC, 2006) \\
LPG & 63.1 (IPCC, 2006) \\
\hline
\end{tabular}

On the other hand, the $\mathrm{CO}_{2}$ emissions caused by energy were estimated through multiplying the energy consumption for each fuel type by its corresponding $\mathrm{CO}_{2}$ emission factor for Indonesia obtained from (IEA, 2012) and (IPCC, 2006) as shown in Table 2. The $\mathrm{CO}_{2}$ emissions released during the combustion of biomass was assumed to be balanced by the $\mathrm{CO}_{2}$ removed from the atmosphere during growth of new biomass (Gustavsson \& Joelsson, 2010). The total $\mathrm{CO}_{2}$ emissions of respective houses were calculated by adding the emissions for each of the energy of end-uses.

\section{Results and discussion}

\subsection{Operational energy}

Figure 3 presents the ownership levels of major household appliances in the case study. As shown, light bulbs, televisions, rice cooker, water dispenser, desktop PC, electric iron and refrigerators recorded high ownership levels. The ownership level of cooling (stand fan) accounts for $0 \%-30 \%$ in Bandung. This low ownership level is mainly because Bandung experiences relatively cool climate as explained before.

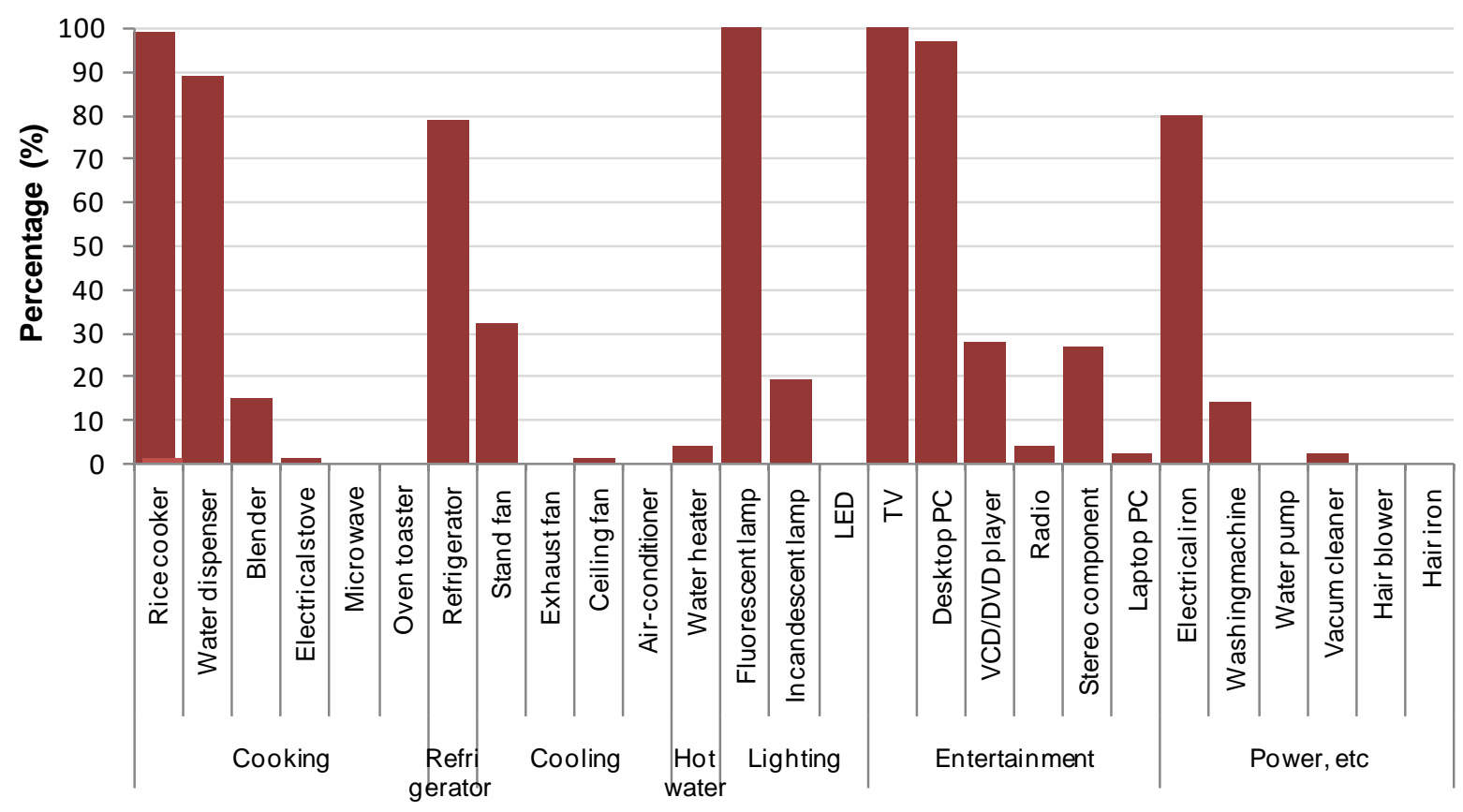

Fig. 3. Ownership level of appliances. 
Figure 4 shows the annual household energy consumption averaged by different end-use categories. Overall, the average annual energy consumption of all samples in Bandung is approximately 9.8 GJ. As shown, it was found that the cooking accounts for the largest percentage (48\%), followed by fridge (10\%), lighting (9\%), etc. the energy consumption for cooling accounts for $3 \%$ on average. Hence, basically, the average household energy consumption of house units increases with the increase in ownership and use of cooking end-use (rice cooker), lighting and the entertainment. Energy consumption caused by electricity use is larger than by LPG: $90 \%$ for apartments in Bandung.

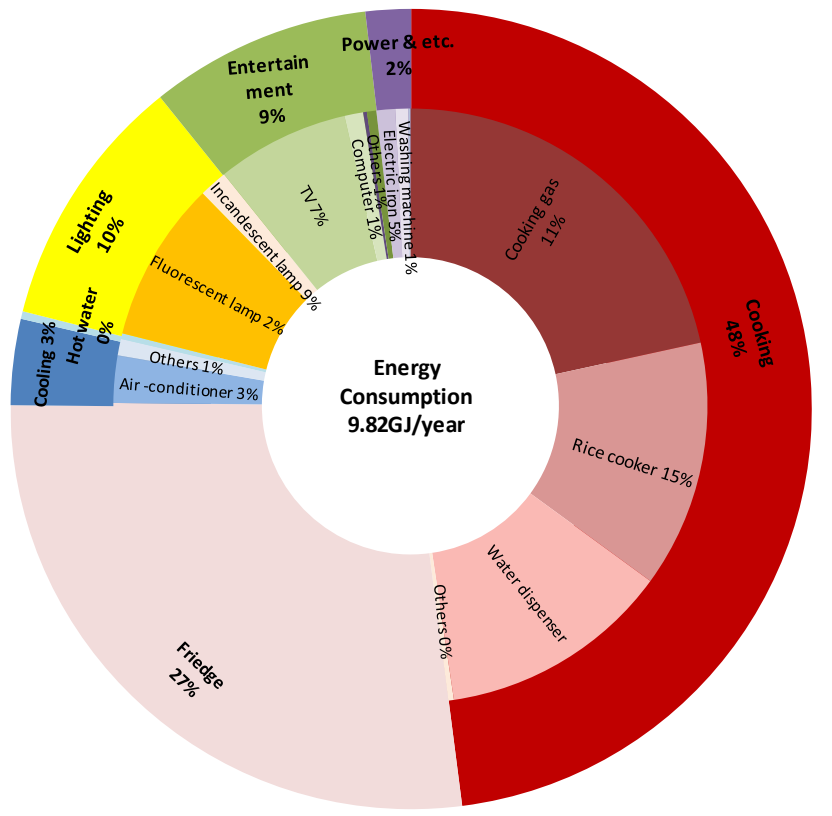

Fig. 4. Annual household energy consumption (GJ/year).

\subsection{Operational $\mathrm{CO}_{2}$ emissions}

The annual household $\mathrm{CO}_{2}$ emissions were estimated through multiplying the energy consumption for each fuel type by its corresponding $\mathrm{CO}_{2}$ emission factor. The profiles of $\mathrm{CO}_{2}$ emissions are similar to those of energy. The average annual $\mathrm{CO}_{2}$ emission is estimated at 1.7 ton $\mathrm{CO}_{2}$-equivalent for apartments. The major contributors are cooking $(0.7$ ton $(39 \%))$, refrigerator $(0.5$ ton $(32 \%))$, and lighting $(0.2$ ton $(12 \%))$. Cooling itself accounted only 0.1 ton $(4 \%)$ due to cool and humid climate of Bandung.

A major step in the environmental impact reduction of a building would be to improve the environmental performance of the energy system that services a building such as energy generation technologies. A shift to power generation technologies, which use fossil fuels in a cleaner and more efficient manner (e.g. more natural gas, hydrogen fuel cells) or use renewable power sources, would go a long way towards reducing environmental impact. While currently, renewable power system are still cost prohibitive in many cases, the net energy ratio (electricity generated/total fossil fuel input) for wind, photovoltaic and biomass electricity generation systems are significantly better than any contemporary utility power systems (Mann \& Spath, 1997; Schleisner, 2000). Further these technologies are improving rapidly, costs are dropping and market share of renewable is increasing yearly. The implementation of renewable technologies would dramatically reduce the operation phase burden of a building. 
Life cycle distribution of energy consumption and environmental impacts are concentrated in the operational phase of building. In all measurements, operation accounted for more than $80 \%$ of inventoried environmental burdens. The optimization of operational phase performance should still be the primary emphasis for the design, until it is evident that there is significant shift in distribution of life cycle burdens.

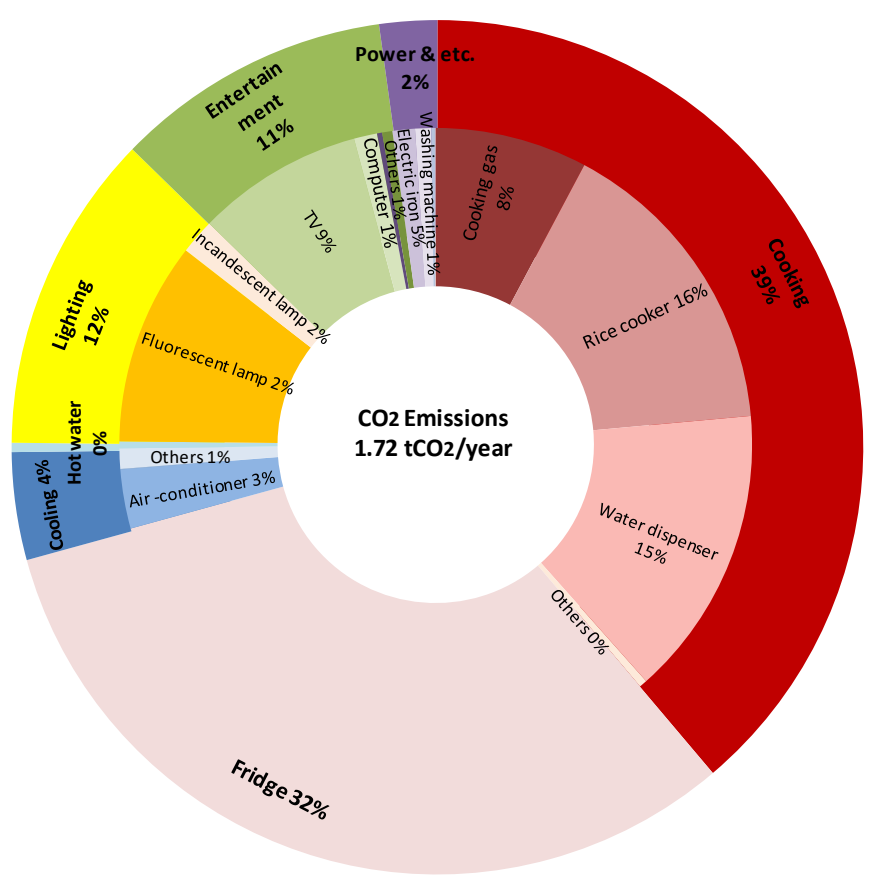

Fig. 5. Annual $\mathrm{CO}_{2}$ emissions (tCO2-eq/year).

\section{Conclusion}

We investigated household energy consumption profiles in Bandung in order to identify the profiles of household energy consumption and $\mathrm{CO}_{2}$ emissions in major cities of Indonesia.

- The average annual energy consumption of all samples in Bandung was approximately $9.8 \mathrm{GJ}$.

- The energy consumption for cooking, fridge, lighting and entertainment largely influenced the increase in the overall energy consumption. Accordingly, the average annual $\mathrm{CO}_{2}$ emission in Bandung was 1.7 ton $\mathrm{CO}_{2-}$ equivalent for apartment.

- In conclusion, it is important to reduce energy consumption/ $/ \mathrm{CO}_{2}$ emissions caused by cooking and friedge as the potential energy-saving strategies soon by finding out renewable energy sources, encouraging efficiency improvement of cooking appliances and friedge usage such as using better insulation, changing setting point temperature of fridge, etc.

\section{Acknowledgments}

This research was supported by Lecturer development Grant of Universitas Pendidikan Indonesia (UPI) 2016. We would also like to thank to Sri Mulyani and the students of UPI who kindly assisted our survey. 


\section{References}

Asian Development Bank. (2010). Key Indicators for Asia and the Pacific 2010 (41st ed.). Mandaluyong: Asian Development Bank.

BAPPEDA Kota Bandung. (2014). Perencanaan Penggunaan Lahan Bandung, Jawa Barat. Bandung: BAPPEDA Kota Bandung.

BPS Kota Bandung. (2013). Kota Bandung Dalam Angka. Bandung.

Bryant, F. B., \& Yarnold, P. R. (1995). Principal-Components Analysis and Exploratory and Confirmatory Factor Analysis. In L. G. Grimm \& P. R. Yarnold (Eds.), Reading and understanding multivariate statistics (p. 371). Washington: American Psychological Association. Retrieved from http://www.apa.org/pubs/books/4316510.aspx?tab=2

Gustavsson, L., \& Joelsson, A. (2010). Life cycle primary energy analysis of residential buildings. Energy and Buildings, 42(2), 210-220. https://doi.org/10.1016/j.enbuild.2009.08.017

IEA. (2012). CO2 Emissions from Fuel Combustion 2012. Paris: OECD Publishing. https://doi.org/10.1787/co2_fuel-2012-en

IPCC. (2006). IPCC Guidelines for National Greenhouse Gas Inventories Volume 2 Energy. (S. Eggleston, L. Buendia, Miwa Kyoko, T. Ngara, \& K. Tanabe, Eds.) (Volume). Kanagawa.

JETRO. (2011). Market investment attraction-Indonesia (in Japanese).

Kurdi, S. Z. (2005). Rumusan Hasil Lokakarya Faktor-Faktor Penentu Emisi CO2 pada Perumahan dan Permukiman Perkotaan. Bandung.

Mann, M. K., \& Spath, P. L. (1997). Life Cycle Assessment of a Biomass Gasification Combined-Cycle System Life Cycle Assessment Life Cycle Assessment of a Biomass Gasification Combined-Cycle Power System. Retrieved from http://www.nrel.gov/docs/legosti/fy98/23076.pdf

PEMPROV JABAR. (2011). Tahun ini Dibangun 100 Tower Rusunawa. Retrieved July 7, 2016, from http://www1.jabarprov.go.id/index.php/news/2529/2011/06/19/Tahun-ini-Dibangun-100-Tower-Rusunawa

PUSDATIN ESDM. (2014). Handbook of Energy \&amp; Economic Statistics of Indonesia. Jakarta: Ministry of Energy and Mineral Resources Republic of Indonesia.

Schleisner, L. (2000). Life cycle assessment of a wind farm and related externalities. Renewable Energy, 20(3), 279-288. https://doi.org/10.1016/S0960-1481(99)00123-8

United Nation. (2014). World Urbanization Prospect. New York.

Utama, A., \& Gheewala, S. H. (2008). Life cycle energy of single landed houses in Indonesia. Energy and Buildings, 40(10), $1911-1916$. https://doi.org/10.1016/j.enbuild.2008.04.017

Utama, A., \& Gheewala, S. H. (2009). Indonesian residential high rise buildings: A life cycle energy assessment. Energy and Buildings, 41(11), 1263-1268. https://doi.org/10.1016/j.enbuild.2009.07.025 
-This page intentionally left blank-

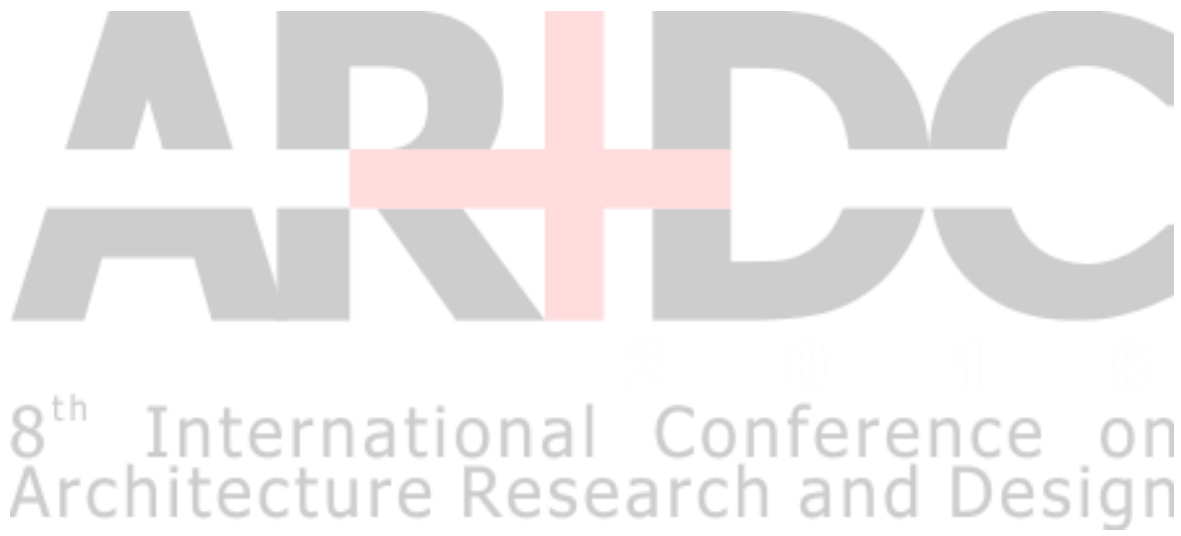

